\title{
Forage responses to lime and nitrogen fertiliser on land converted from pine forest to dryland pasture in Canterbury
}

\author{
L.M. CONDRON, D.J. MOOT, A.J. MARSHALL, P.J. WHITE and G.R. EDWARDS \\ Agriculture and Life Sciences Division, Lincoln University, Lincoln 7647, Lincoln \\ CONDRONL@lincoln.ac.nz
}

\begin{abstract}
A field trial was established to quantify the impacts of lime $(0,2.5,5$ and $10 \mathrm{t} / \mathrm{ha})$ and nitrogen $(\mathrm{N})$ fertiliser $(0$, $50,100,200$ and $400 \mathrm{~kg} \mathrm{~N} / \mathrm{ha} /$ year) addition on the dry matter (DM) production of a crop sequence of triticale followed by dryland pasture that was established on a site converted from long-established plantation forestry. Results are reported for the first 22 months. The application of lime up to $10 \mathrm{t} /$ ha had no effect on triticale DM production. In the subsequent pasture, the percentage of clover increased from $15 \%$ without lime to $25-30 \%$ when 5-10 t/ha of lime was applied. Lime application only increased pasture DM production in the last 4 months. Annual pasture DM production increased significantly with increasing levels of $\mathrm{N}$ fertiliser application from $5.3 \mathrm{t} \mathrm{DM} /$ ha with no $\mathrm{N}$ applied to $7.5 \mathrm{t}$ $\mathrm{DM} / \mathrm{ha}$ at $400 \mathrm{~kg} \mathrm{~N} / \mathrm{ha}$. The observed response to $\mathrm{N}$ addition was mainly attributed to the low $\mathrm{N}$ status of the soil following conversion, which in turn was compounded by the ongoing decomposition of large quantities of mulched woody debris.
\end{abstract}

Keywords: land-use conversion, plantation forestry, pasture, lime; nitrogen fertiliser

\section{Introduction}

Changes in vegetation and land-use have occurred throughout the human habitation and development of New Zealand. Most recently, there has been a shift from conifer plantation forest to pasture on flat and rolling hill country. This has been driven by a recovery in the economic viability of pastoral farming combined with a significant decline in the value of timber exports since the early 1990s. The absence of fertiliser and lime inputs to plantation forests means that the soil fertility under long-term short rotation forestry is often very poor, including high levels of soil acidity and depleted nutrient content (Alfredsson et al. 1998; Groenendijk et al. 2002; Condron 2006). Thus, successful conversion from long established plantation forest to productive pasture will require significant inputs of lime and fertiliser, while the incorporation and subsequent decomposition of significant quantities of woody debris during conversion is likely to have an impact on the availability of key nutrients such as nitrogen $(\mathrm{N})$. This paper reports findings from part of a programme of work investigating the conversion of pine forest owned by the Selwyn Plantation
Board Limited on the Canterbury plains to productive grass-legume dryland pastures. The specific objective of this trial was to examine the effects of different rates of lime and nitrogen fertiliser on production of a crop sequence of triticale followed by a dryland pasture that was established.

\section{Materials and Methods \\ Experimental site}

The trial was located on a 30 ha dryland research site at Darfield, Canterbury. The site had been through three rotations of timber production between 1890 and 2003. Pinus radiata were felled and timber cleared during 2004. Following the removal of larger timber waste to burn piles, stumps and woody debris were mulched from September 2004 to March 2005. The site was then cultivated in preparation for sowing of crops and pastures in April 2005.

The soil type is a Lismore stony silt loam. The soil was littered with woody debris throughout the profile and on the surface. The quantity of mulched woody debris in the topsoil was difficult to quantify and varied widely across the site, but would have exceeded $50 \mathrm{t} / \mathrm{ha}$ (L. Condron unpublished data). Soil tests taken in March 2005 after site clearing and mulching showed that, as expected, soil pH was very low (4.6) with high levels of exchangeable aluminium $(2.5 \mathrm{me} / 100 \mathrm{~g}, \mathrm{KCl}$ extractable $)$, while concentrations of total phosphorus $(400 \mathrm{mg} / \mathrm{kg})$ and sulphur $(250 \mathrm{mg} / \mathrm{kg})$ were very low. The high concentration of organic carbon $(5.9 \%)$ and low total $\mathrm{N}$ content $(0.25 \%)$ resulted in a relatively high carbon (C) to $\mathrm{N}$ ratio (24, not including larger pieces of wood).

\section{Experimental design}

The experiment was a split plot factorial design, replicated three times, with lime rate as the main factor and nitrogen rate as the sub factor. The treatments were standard agricultural lime at four rates $(0,2.5,5$ and $10 \mathrm{t} / \mathrm{ha})$ and Calcium ammonium nitrate fertiliser $(26 \% \mathrm{~N})$ at five rates $(0,50,100,200,400 \mathrm{~kg} \mathrm{~N} / \mathrm{ha})$ giving 60 plots. Main plots were $20 \mathrm{~m} \times 6 \mathrm{~m}$ and sub plots were $4 \mathrm{~m} \mathrm{x} 6$ $\mathrm{m}$. Based on results from soil tests, the site was fertilised with $300 \mathrm{~kg}$ superphosphate $/ \mathrm{ha}, 0.5 \mathrm{~kg}$ boron/ha and 5 $\mathrm{kg}$ copper sulphate/ha in March 2005. Lime and fertiliser were surface applied and incorporated to a depth of approximately $100 \mathrm{~mm}$ by a roto-crumbler immediately 
Figure 1 Mean botanical composition (\%, untransformed) on a species basis at (a) four lime rates and (b) five nitrogen fertiliser rates on 19 October 2006.
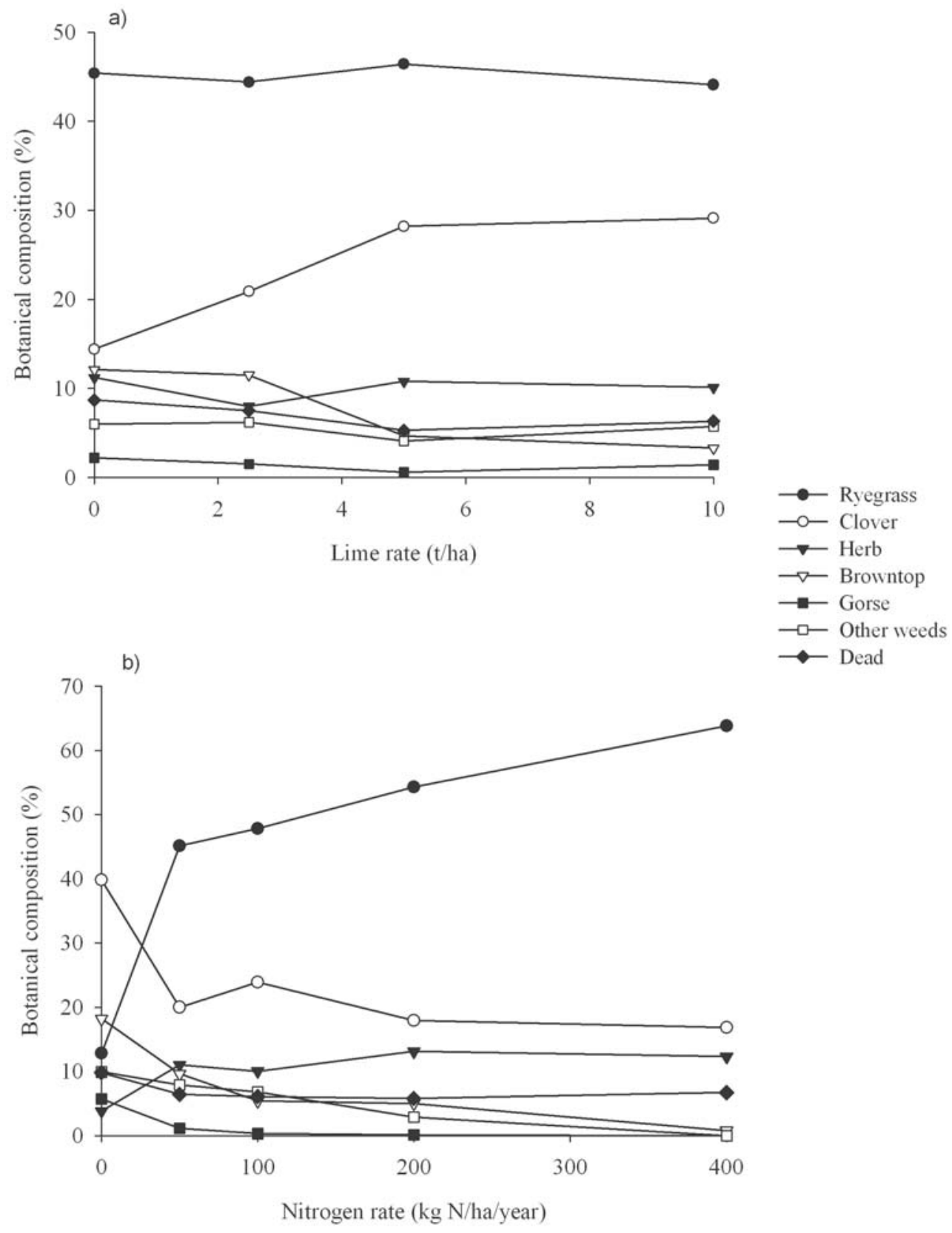

prior to sowing. Soil measurements taken in September 2006, 18 months after lime application, showed soil $\mathrm{pH}$ values of: $0 \mathrm{t} / \mathrm{ha}=4.7,2.5 \mathrm{t} / \mathrm{ha}=5.4,5 \mathrm{t} / \mathrm{ha}=5.6,10 \mathrm{t} /$ ha $=5.9$.

Triticale (x Triticosecale Wittmack) cultivar 'Agricom Double Take' was sown at $150 \mathrm{~kg} /$ ha on 2 April 2005. On 21 April 2005, nitrogen fertiliser was applied at the treatment rates in a single application. The aim was to test the response of the first forage crop to a pulsed application of $\mathrm{N}$, and thus gain quick information on the size of $\mathrm{N}$ responses on recently converted soils. The triticale was grazed to a residual of $600 \mathrm{~kg} \mathrm{DM} /$ ha on 15 September, and the residual was topped with a mower to ground level. A pasture mixture of $15 \mathrm{~kg} / \mathrm{ha}$ 'Meridian' perennial ryegrass (Lolium perenne), $3 \mathrm{~kg} / \mathrm{ha}$ 'Grasslands Demand' white clover (Trifolium repens), $4 \mathrm{~kg} / \mathrm{ha}$ 
'Grasslands Pawera' red clover (Trifolium pratense), 1 $\mathrm{kg} / \mathrm{ha}$ 'Grasslands Puna' chicory (Cichorium intybus) and $1 \mathrm{~kg} / \mathrm{ha}$ 'Grasslands Lancelot' plantain (Plantago lanceolata) was direct drilled into the plots on 28 September 2005. From this point onwards, nitrogen fertiliser treatments were continued on the same plots, but were altered to annual rates of application, with the total amount split into three equal applications in autumn (April), early spring (August) and mid spring (October). The plots were grazed in common five times between February 2006 and February 2007 with Corriedale ewes and hoggets at a stocking rate of 600 sheep/ha. The aim was to leave pasture residuals of 700-900 $\mathrm{kg} \mathrm{DM} / \mathrm{ha}$, with grazing typically taking 1-2 days. Compared to the long term average $(777 \mathrm{~mm})$, there was less rainfall in 2005 (485 mm) and more in 2006 (888 mm). Full climate details for the site are given in Moot et al. (2007).

\section{Measurements}

Triticale DM was assessed pre grazing on 8 September 2005 by taking 10 rising plate meter measurements per plot. The meter readings were calibrated by $20 \times 0.2 \mathrm{~m}^{2}$ quadrats cut across a range of treatments. Pasture mass was assessed pre- and post-grazing from February 2006 to February 2007 by taking 10 rising plate meter measurements per plot. The meter readings were calibrated each time by $20 \times 0.2 \mathrm{~m}^{2}$ quadrats cut across a range of treatments. The percentage of each species in the pasture on a DM basis was assessed visually in two $0.2 \mathrm{~m}^{2}$ quadrats per plot on 19 October 2006. Visual estimates were calibrated against $20 \times 0.2 \mathrm{~m}^{2}$ quadrats cut across a range of treatments, with a sub-sample sorted to species, and oven dried. Data were analysed by ANOVA of a split plot design. Percentage botanical composition data were arcsine transformed prior to ANOVA. Untransformed percentage data are presented in Figure 1, but all tests of significance were done on the transformed scale.

\section{Results \\ Triticale DM production}

Lime rate had no significant effect on triticale DM production (Table 1). Triticale DM production was greater where $\mathrm{N}$ was applied than not applied, but did not differ among 50, 100, 200 and $400 \mathrm{~kg} \mathrm{~N} / \mathrm{ha}$ (Table 1). Nitrogen efficiency of triticale DM production was very high (34.6 $\mathrm{kg} \mathrm{DM} / \mathrm{kg} \mathrm{N}$ applied) at $50 \mathrm{~kg} \mathrm{~N} / \mathrm{ha}$ and declined with increasing $\mathrm{N}$ rate (Table 1). There was no significant interaction between lime rate and $\mathrm{N}$ rate for triticale DM production.

\section{Pasture DM production}

Lime rate had no effect on pasture DM production in the pasture establishment phase, autumn and winter (Table
Table 1 Mean triticale production ( $\mathrm{kg} \mathrm{DM} / \mathrm{ha}$ ) and nitrogen efficiency ( $\mathrm{kg} \mathrm{DM} / \mathrm{kg} \mathrm{N}$ applied) at four lime rates and five nitrogen rates on 8 September (159 days after sowing). Means followed by the same letters within a column do not differ significantly according to a LSD $(\alpha=0.05)$ test following a significant ANOVA.

\begin{tabular}{lcc}
\hline & Triticale & Nitrogen efficiency \\
\hline Lime (t/ha) & & \\
0 & $4642 \mathrm{a}$ & \\
2.5 & $4821 \mathrm{a}$ & \\
5 & $4062 \mathrm{a}$ & \\
10 & $4542 \mathrm{a}$ & \\
$\mathrm{P}$ value & 0.33 & \\
LSD & 985 & \\
$\mathrm{~N}$ rate (kg N/ha) & & \\
0 & $2747 \mathrm{a}$ & \\
50 & $4520 \mathrm{~b}$ & 35.5 \\
100 & $4534 \mathrm{~b}$ & 17.9 \\
200 & $5314 \mathrm{~b}$ & 12.8 \\
400 & $5470 \mathrm{~b}$ & 6.8 \\
$\mathrm{P}$ value & 0.01 & \\
LSD & 966 & \\
\hline
\end{tabular}

$2)$. In spring and summer, DM production was significantly greater where lime was applied than with no lime, but did not differ among 2.5, 5 and 10 t/ha. Nitrogen rate had no significant effect on pasture DM production in the establishment phase and autumn (Table 2). In winter and spring, DM production was greater at 200 and $400 \mathrm{~kg} \mathrm{~N} / \mathrm{ha} / \mathrm{yr}$ than at 0,50 and $100 \mathrm{~kg} \mathrm{~N} / \mathrm{ha}$, which all had similar DM production. In summer, DM production was greatest at $400 \mathrm{~kg} \mathrm{~N} / \mathrm{ha}$, with all other N rates having similar DM production. Total annual production was not different between 0 and $50 \mathrm{~kg} \mathrm{~N} / \mathrm{ha}$, but then increased with increasing $\mathrm{N}$ rate. Pasture $\mathrm{N}$ efficiency was lower than in the triticale crop and changed little with $\mathrm{N}$ rate (Table 2). There were no significant interactions between lime rate and $\mathrm{N}$ rate for pasture $\mathrm{DM}$ production in any season.

\section{Pasture botanical composition}

The percentage of clover (combined white and red clover) increased $(\mathrm{P}<0.05)$ with lime rate, but did not differ between 5 and $10 \mathrm{t}$ lime/ha (Fig. 1a). The percentage of browntop declined $(\mathrm{P}=0.03)$ with lime rate. Other species were unaffected by lime rate. The percentage of perennial ryegrass increased and browntop decreased (both $\mathrm{P}<0.01$ ) with increasing $\mathrm{N}$ fertiliser rate (Fig. 1b). The percentage of clover was lower $(\mathrm{P}<0.01)$ where $\mathrm{N}$ fertiliser was applied than not applied but did not differ among 50, 100, 200 and $400 \mathrm{~kg} \mathrm{~N} / \mathrm{ha}$ (Fig. 1b). Gorse declined from $5 \%$ at $0 \mathrm{~kg} \mathrm{~N} / \mathrm{ha} / \mathrm{yr}$ to $<0.2 \%$ at $100 \mathrm{~kg} \mathrm{~N} / \mathrm{ha}$ (Fig. 1b). The percentage of herb (chicory + plantain) was greater $(\mathrm{P}<0.01)$ where $\mathrm{N}$ fertiliser was applied than not applied but did not differ among 50, 100, 200 and 400 
Table 2 Mean pasture grown ( $\mathrm{kg} \mathrm{DM} / \mathrm{ha}$ ) and nitrogen efficiency (kg DM/kg N applied) at four lime rates and five nitrogen rates from sowing on 28 September 2005 to 31 January 2007. Means followed by the same letters within a column do not differ significantly according to a LSD $(\alpha=0.05)$ test following a significant ANOVA. Nitrogen efficiency (kg DM/kg N applied) was calculated from the autumn to summer data.

\begin{tabular}{|c|c|c|c|c|c|c|c|}
\hline & Establishment & Autumn & Winter & Spring & Summer & Annual & $\mathrm{N}$ efficiency \\
\hline \multicolumn{8}{|c|}{ Lime (t/ha) } \\
\hline 0 & $2377 a$ & $1697 a$ & $799 a$ & $1976 b$ & $981 b$ & $5453 a$ & \\
\hline 2.5 & $2377 a$ & $1696 a$ & $713 a$ & $2558 a$ & $1636 a$ & $6604 a$ & \\
\hline 5 & $2450 a$ & $1597 a$ & $700 a$ & $2402 a$ & $1480 a$ & $6179 a$ & \\
\hline 10 & $2198 a$ & $1569 a$ & $770 a$ & $2354 a$ & $1596 a$ & $6289 a$ & \\
\hline$P$ value & 0.77 & 0.84 & 0.39 & 0.04 & 0.04 & 0.12 & \\
\hline LSD & 606 & 438 & 148 & 359 & 439 & 981 & \\
\hline \multicolumn{8}{|c|}{$\mathrm{N}$ rate $(\mathrm{kg} \mathrm{N} / \mathrm{ha})$} \\
\hline 0 & $2251 a$ & $1532 a$ & $512 c$ & $2049 b$ & $1203 b$ & $5295 d$ & \\
\hline 50 & $2216 a$ & $1510 a$ & $599 c$ & $2082 b$ & $1486 a b$ & $5677 d$ & 7.6 \\
\hline 100 & $2490 a$ & $1747 a$ & $647 c$ & $2004 b$ & $1306 b$ & $5704 c$ & 4.1 \\
\hline 200 & $2484 a$ & $1760 a$ & $886 b$ & $2667 a$ & $1355 b$ & $6669 b$ & 6.9 \\
\hline 400 & $2310 a$ & $1850 a$ & $1084 a$ & $2812 a$ & $1764 a$ & $7509 a$ & 5.5 \\
\hline $\mathrm{P}$ value & 0.56 & 0.12 & $<0.001$ & $<0.01$ & 0.02 & $<0.01$ & \\
\hline LSD & 430 & 317 & 167 & 423 & 343 & 789 & \\
\hline
\end{tabular}

Establishment = sowing on 28 September 2005 to 1 February 2006; Autumn = 1 February to 19 May 2006; Winter $=19$ May to 7 September 2006; Spring = 7 September to 11 December 2006; Summer = 11 December 2006 to 31 January 2007.

$\mathrm{kg} \mathrm{N} / \mathrm{ha}$ (Fig. 1b). There were no significant interactions between lime rate and $\mathrm{N}$ rate for pasture DM production in any season.

\section{Discussion}

\section{Lime response}

There was no impact of lime application to this acid soil $(\mathrm{pH}<5.0)$ on $\mathrm{DM}$ production of the triticale in the first 5 months. This is surprising given the low starting soil $\mathrm{pH}$ and the high levels of soluble aluminium $(2.5 \mathrm{me} /$ $100 \mathrm{~g}$ ). The lack of a DM response of triticale to lime application may be attributable to its acid tolerance and suitability for soils where cereal production is marginal (Liu et al. 2004).

It is also notable that DM production of the pasture that was established after the triticale was only increased by lime application in the last 4 months (spring and summer) of the reporting period. In a previous lime trial on a former forestry site, Hawke (2004) found that the application of $4 \mathrm{t}$ lime/ha increased pasture production when measured in the second year after conversion. However, the soil in this case was yellow brown pumice and the effect of aluminium toxicity on pasture production was likely to be more pronounced. The small and slow DM response in the current study may be related to a reduced phytotoxic effect of soluble aluminium on species such as perennial ryegrass. This may be due to an interaction with soluble organic compounds released during initial decomposition of mulched woody debris following pasture establishment. Data from preliminary studies carried out at the Darfield site indicate that $30 \%$ net decomposition of coarse woody debris occurred during the first year following conversion. The decomposition rate of finer material which makes up most of the mulched woody debris will be greater than this, and additional studies are being carried out to quantify woody debris decomposition and its impact on soil properties and processes, including the bioavailability of aluminium in soil.

The effect of lime application on botanical composition was more pronounced, with the percentage of clover in the pasture increasing significantly from $15 \%$ without lime to $25-30 \%$ when $5-10 \mathrm{t} / \mathrm{ha}$ of lime was applied. Furthermore, the perennial grass weed browntop declined with increasing rates of lime. The effect of lime rate on clover was as expected, and can be directly attributed to the amelioration of phytotoxic soluble aluminium, especially since clover is known to be very sensitive to soluble aluminium in soil (Adams 1984; Edmeades et al. 1983).

\section{$\mathrm{N}$ response}

The consistent and generally positive DM response to $\mathrm{N}$ fertiliser addition can be attributed to the low $\mathrm{N}$ status of the soil following conversion. This was reflected in the high ratio of $\mathrm{C}$ to $\mathrm{N}$ in the soil at crop establishment (24) compared with the optimal ratio of $12-15$ for productive pasture. The high soil $\mathrm{C}: \mathrm{N}$ ratio resulted in net immobilisation of $\mathrm{N}$ which would have been compounded by the ongoing decomposition of fine and coarse woody debris as described above which has a $\mathrm{C}: \mathrm{N}$ ratio of $>250$. Accordingly, the addition of soluble $\mathrm{N}$ fertiliser would have dramatically improved levels of plant available $\mathrm{N}$ and forage production. Some of the 
applied $\mathrm{N}$ will have been converted to organic $\mathrm{N}$ in soil via microbial immobilisation but will be released by mineralisation as woody debris decomposition continues and soil C:N ratio declines (Kelley \& Stevenson 1996).

\section{Conclusion and Practical Implications}

The results of the first 22 months of this study indicate that lime application at greater than $5 \mathrm{t} / \mathrm{ha}$ to ex-forestry sites is important in order to establish pastures of high legume content and to suppress invasion of weed species such as browntop. In the longer term, these soils which are in an early stage of transition, are likely to respond more strongly to the full effects of $\mathrm{pH}$ amelioration, and greater DM production responses in the pasture may be expected than those recorded so far. Given that the legume content doubled as a result lime application it may be reasonably expected that as $\mathrm{N}$ fixation and subsequent cycling of this fixed $\mathrm{N}$ under grazing occurs, the $\mathrm{N}$ status of the soil will increase, and the response to $\mathrm{N}$ fertiliser inputs may decline.

\section{ACKNOWLEDGEMENTS}

Selwyn Plantation Board Limited provided financial support for this project.

\section{REFERENCES}

Adams, F. 1984. Soil Acidity and Liming. Second Edition. ASA-CSSA-SSSA. Madison, Wisconsin, USA. 390 pp.

Alfredsson, H.; Condron, L.M.; Clarholm, M; Davis, M.R. 1998. Changes in soil acidity and organic matter following the establishment of conifers on former grassland in New Zealand. Forest Ecology and Management 112: 245-252.

Condron, L.M. 2006. Land-use change and soil fertility: a New Zealand perspective. 18th World Congress of Soil Science. Philadelphia, USA. Oral Presentation 82-4. Abstract on CD-ROM [IUSS, 2006].

Edmeades, D.C.; Smart, C.E.; Wheeler, D.M. 1983. Aluminium toxicity in New Zealand soils: preliminary results on the development of diagnostic criteria. New Zealand Journal of Agricultural Research 26: 493-501.

Groenendijk, F.M.; Condron, L.M.; Rijkse, W.C. 2002. Effects of afforestation on organic carbon, nitrogen and sulfur concentrations in New Zealand hill country soils. Geoderma 108: 91-100.

Hawke, M.F. 2004. Conversion of forestry land back to productive pasture. Proceedings of the New Zealand Grassland Association 66: 157-162.

Kelley, K.R.; Stevenson, F.J. 1996. Organic forms of N in soil. pp. 407-427. In: Humic Substances in Terrestrial Ecosystems. Ed. Piccolo A. Elsevier, Amsterdam.

Liu, D.L; Helyar, K.R.; Conyars, M.K.; Fisher, R.; Polie, G.J. 2004. Response of wheat, triticale and barley to lime application in semi-arid soils. Field Crops Research 90: 287-301.

Moot, D.J.; Mills, A. Marshall, A.; Edwards, G.R. 2007. Lucerne establishment sequences to maximise weed control in ex- Pinus radiata plantations. Proceedings of the New Zealand Grassland Association 69: 99-105. 